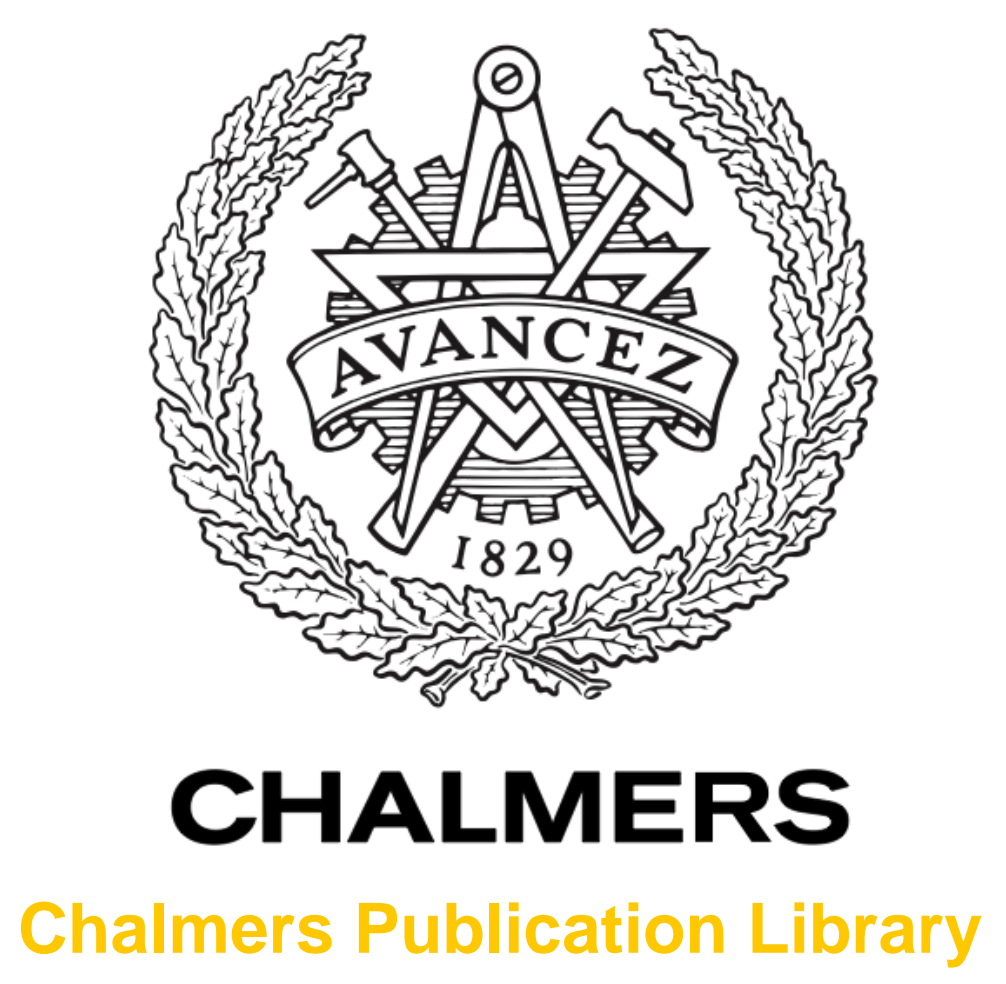

\title{
Ammonium recovery from reject water combined with hydrogen production in a bioelectrochemical reactor
}

This document has been downloaded from Chalmers Publication Library (CPL). It is the author's version of a work that was accepted for publication in:

Bioresource Technology (ISSN: 0960-8524)

Citation for the published paper:

Wu, X. ; Modin, O. (2013) "Ammonium recovery from reject water combined with hydrogen production in a bioelectrochemical reactor". Bioresource Technology, vol. 146 pp. 530-536.

http://dx.doi.org/10.1016/j.biortech.2013.07.130

Downloaded from: http://publications.lib.chalmers.se/publication/182217

Notice: Changes introduced as a result of publishing processes such as copy-editing and formatting may not be reflected in this document. For a definitive version of this work, please refer to the published source. Please note that access to the published version might require a subscription.

Chalmers Publication Library (CPL) offers the possibility of retrieving research publications produced at Chalmers University of Technology. It covers all types of publications: articles, dissertations, licentiate theses, masters theses, conference papers, reports etc. Since 2006 it is the official tool for Chalmers official publication statistics. To ensure that Chalmers research results are disseminated as widely as possible, an Open Access Policy has been adopted.

The CPL service is administrated and maintained by Chalmers Library. 
This article, "Ammonium recovery from reject water combined with hydrogen production in a bioelectrochemical reactor" by Xue Wu and Oskar Modin, was published in Bioresource Technology, volume 146, pp. 530-536, year 2013.

DOI: http://dx.doi.org/10.1016/j.biortech.2013.07.130 


\title{
Ammonium recovery from reject water combined with hydrogen production in a bioelectrochemical reactor
}

\author{
Xue Wu, Oskar Modin ${ }^{*}$ \\ Division of Water Environment Technology, Civil and Environmental Engineering, Chalmers University of Technology, \\ SE-41296 Gothenburg, Sweden (Email: sherrywu7@hotmail.com, oskar.modin@chalmers.se) \\ *Corresponding author. Tel: +46 317722138
}

\begin{abstract}
In this study, a bioelectrochemical reactor was investigated for simultaneous hydrogen production and ammonium recovery from reject water, which is an ammonium-rich side-stream produced from sludge treatment processes at wastewater treatment plants. In the anode chamber of the reactor, microorganisms converted organic material into electrical current. The electrical current was used to generate hydrogen gas at the cathode with $96 \pm 6 \%$ efficiency. Real or synthetic reject water was fed to the cathode chamber where proton reduction into hydrogen gas resulted in a $\mathrm{pH}$ increase which led to ammonium being converted into volatile ammonia. The ammonia could be stripped from the solution and recovered in acid. Overall, ammonium recovery efficiencies reached $94 \%$ with synthetic reject water and $79 \%$ with real reject water. This process could potentially be used to make wastewater treatment plants more resource-efficient and further research is warranted.
\end{abstract}

Keywords: Microbial electrolysis cell; nitrogen recovery; sludge liquor; anaerobic digester centrate

\section{Introduction}

Nitrogen removal from wastewater is important to protect receiving water bodies from eutrophication. The conventional method is biological nitrification and denitrification. In the nitrification process, ammonium is aerobically oxidized to nitrite $\left(\mathrm{NO}_{2}{ }^{-}\right)$and nitrate $\left(\mathrm{NO}_{3}{ }^{-}\right)$by ammonium-oxidizing and nitrite-oxidizing microorganisms. Then under anoxic conditions, nitrate is reduced to nitrogen gas by denitrifying microorganisms typically using organic compounds as electron donor. This nitrogen removal process is uneconomical as aeration is needed to support nitrification and organic material is needed to support denitrification. A better alternative is the newly developed anammox process, in which microorganisms convert ammonium and nitrite to nitrogen gas (Jetten et al., 1999). This saves aeration cost as only about half of the ammonium needs to be oxidized to nitrite. Moreover, there is no need for an organic electron donor. The anammox process is accomplished by slow-growing microorganisms and has primarily been investigated for treatment of concentrated side-streams (Fux et al., 2002). Both the conventional method and anammox converts ammonium in wastewater into harmless nitrogen gas. Although, this does treat the wastewater, it does not recover nitrogen in any usable form. Nitrogen is an important fertilizer and about $1 \%$ of the world's total generated energy is used in the Haber-Bosch process to convert dinitrogen gas from air into ammonium, which can be used as fertilizer (Smith, 2002). A more sustainable system for wastewater treatment should therefore aim at recovering nitrogen rather than just removing it from the water stream. In wastewater treatment plants, sludge dewatering processes usually produces reject water with high ammonium content (Arnold et al., 2000). The concentration of ammonium-nitrogen can often be as high as 1000 
$\mathrm{mg} / \mathrm{L}$. The reject water is recycled back to the influent and imposes a high nitrogen load to the plant. Since the reject water stream has a relatively high concentration of ammonium, it might be suitable for nitrogen recovery. In this study, a bioelectrochemical reactor for nitrogen recovery from reject water was investigated.

In bioelectrochemical systems (BESs), which include microbial fuel cells (MFCs) and microbial electrolysis cells (MECs), living microorganisms catalyze anode and/or cathode reactions (reviewed in e.g. Rozendal et al., 2008). In an MFC, organic matter is oxidized by microorganisms at the anode. The liberated electrons travel through an external circuit to the cathode where oxygen is reduced. Electrical energy can be recovered from the external circuit because the overall reaction is thermodynamically favorable (Logan et al., 2006). In an MEC, a voltage is applied to the system to drive a thermodynamically unfavorable reaction at the cathode. For example, hydrogen gas can be produced by reduction of hydrogen ions in the water (Logan et al., 2008). In most MFC and MEC designs, the anode and cathode are separated by an ion exchange membrane. As electrons travel from the anode to the cathode through the external circuit, ions migrate through the membrane to maintain charge balance in the system. This phenomenon could potentially be used to improve nitrogen removal or recovery in wastewater treatment plants.

Both bioelectrochemical reactors and abiotic electrochemical reactors have been used to recover ammonium from wastewater streams. The strategy by researchers thus far has been to feed the wastewater to the anode chamber and concentrate the ammonium in the cathode chamber by migration of the ammonium ions through a cation exchange membrane. Then, the ammonium can be recovered through volatilization at high $\mathrm{pH}$ followed by capture in an acid. If the wastewater also contains organic material, the system can be operated as a microbial fuel cell, which means that no electrical energy input is needed to drive the electrochemical reactor (Kuntke et al., 2011). This is the case for urine treatment, which contains high concentrations of both organics and nitrogen (Kuntke et al., 2012). Reject water, however, has very low concentration of biodegradable organics. Therefore, the electrochemical system must be operated abiotically (Desloover et al., 2012). This requires a larger input of electrical energy compared to bioelectrochemical reactors.

In this study, a different strategy to recover ammonium from reject water was used. By feeding influent wastewater to the anode chamber, current generation by biocatalyzed oxidation of organics is made possible. The reject water is directly fed to the cathode compartment where protons are reduced to hydrogen gas on the cathode surface. The use of a cation exchange membrane to separate the electrodes causes a pH shift between the two compartments (Rozendal et al., 2006). However, as the flow of influent wastewater is typically 100 times larger than the flow of reject water at a wastewater treatment plant, the $\mathrm{pH}$ drop (or alkalinity concentration consumption) at the anode will be relatively small whereas the $\mathrm{pH}$ rise (or alkalinity concentration increase) at the cathode will be relatively large. This strategy was previously used by Modin et al. (2011). However, they used an MFC and focused on supporting the nitritation process which is an alkalinity-consuming reaction for oxidizing ammonium to nitrite. In this study, the strategy is used to recover ammonium and simultaneously produce hydrogen gas. The increase of reject water $\mathrm{pH}$ causes a shift in the chemical equilibrium between 
ammonium $\left(\mathrm{NH}_{4}{ }^{+}\right)$and ammonia $\left(\mathrm{NH}_{3}\right)$. Ammonia can then be volatilized and captured in hydrochloric acid. By operating the bioelectrochemical reactor as a MEC, ammonia recovery can be combined with production of hydrogen gas.

\section{Materials and methods}

\subsection{Experimental setup}

The bioelectrochemical reactor consisted of anode and cathode chambers with internal dimensions $3 \mathrm{x}$ $3 \times 10 \mathrm{~cm}^{3}$. The two chambers were separated by a cation exchange membrane with a cross section of $7.1 \mathrm{~cm}^{2}$ (CMI-7000, Membranes International Inc.). Two pieces of carbon felt $\left(8 \times 3.7 \times 0.2 \mathrm{~cm}^{3}\right)$, attached to graphite rods ( $9 \mathrm{~cm}$ long, $0.5 \mathrm{~cm}$ diameter) were used as anode material, while the cathode was a steel wire $37 \mathrm{~cm}$ long and $0.81 \mathrm{~mm}$ in diameter.

Both the anode and cathode chamber were fed batchwise. A synthetic wastewater was circulated through the anode chamber from 1 litre bottle at a flow rate of $55 \mathrm{~mL} / \mathrm{min}$. The total anolyte volume was $1.1 \mathrm{~L}$. The synthetic wastewater contained $20 \mathrm{mM} \mathrm{CH}_{3} \mathrm{COONa}, 100 \mathrm{mM}$ phosphate buffer (pH 7.2) and a nutrient solution. The composition of the nutrient solution was as follows (mg/L): $2925 \mathrm{NaCl}$, $100 \mathrm{MgSO}_{4} \bullet 7 \mathrm{H}_{2} \mathrm{O}, 100 \mathrm{CaCl}_{2} \bullet 2 \mathrm{H}_{2} \mathrm{O}, 100 \mathrm{NH}_{4} \mathrm{Cl}, 2 \mathrm{FeCl}_{2} \bullet 4 \mathrm{H}_{2} \mathrm{O}, 0.05 \mathrm{H}_{3} \mathrm{BO}_{3}, 0.05 \mathrm{ZnCl}_{2}, 0.03 \mathrm{CuSO}_{4}$, $0.5 \mathrm{MnCl}_{2} \bullet 4 \mathrm{H}_{2} \mathrm{O}, 0.05\left(\mathrm{NH}_{4}\right) \mathrm{Mo}_{7} \mathrm{O}_{24}, 0.05 \mathrm{AlCl}_{3}, 0.05 \mathrm{CoCl}_{2} \bullet 6 \mathrm{H}_{2} \mathrm{O}, 0.05 \mathrm{NiCl}_{2}, 0.1 \mathrm{Na}_{2} \mathrm{SeO}_{3}, 0.05$ $\mathrm{Na}_{2} \mathrm{WO}_{4} \cdot 2 \mathrm{H}_{2} \mathrm{O}$. The cathode chamber was loaded with $80 \mathrm{~mL}$ reject water. Both synthetic and real reject water collected from a wastewater treatment plant in Gothenburg, Sweden, were used in the experiments. The synthetic reject water consisted of $50 \mathrm{mM} \mathrm{KCl}$ and $71.4 \mathrm{mM} \mathrm{NH}_{4} \mathrm{Cl}$ (which corresponds to $1000 \mathrm{mg} \mathrm{N} / \mathrm{L}$ ). The real reject water had an ammonium concentration of about $1000 \mathrm{mg}$ $\mathrm{N} / \mathrm{L}$ as well.

Hydrogen gas produced in the cathode chamber was bubbled through $10 \mathrm{~mL} 2 \mathrm{M} \mathrm{HCl}$ in order to capture $\mathrm{NH}_{3}$ present in the gas flow. To recover the $\mathrm{NH}_{3}$ that was not captured from the $\mathrm{H}_{2}$ gas flow, the reject water was sparged with air at the end of each experiment. The air flow was passed through four tubes, each containing $4 \mathrm{~mL} 2 \mathrm{M} \mathrm{HCl}$. The experimental setup is depicted in Figure 1. 


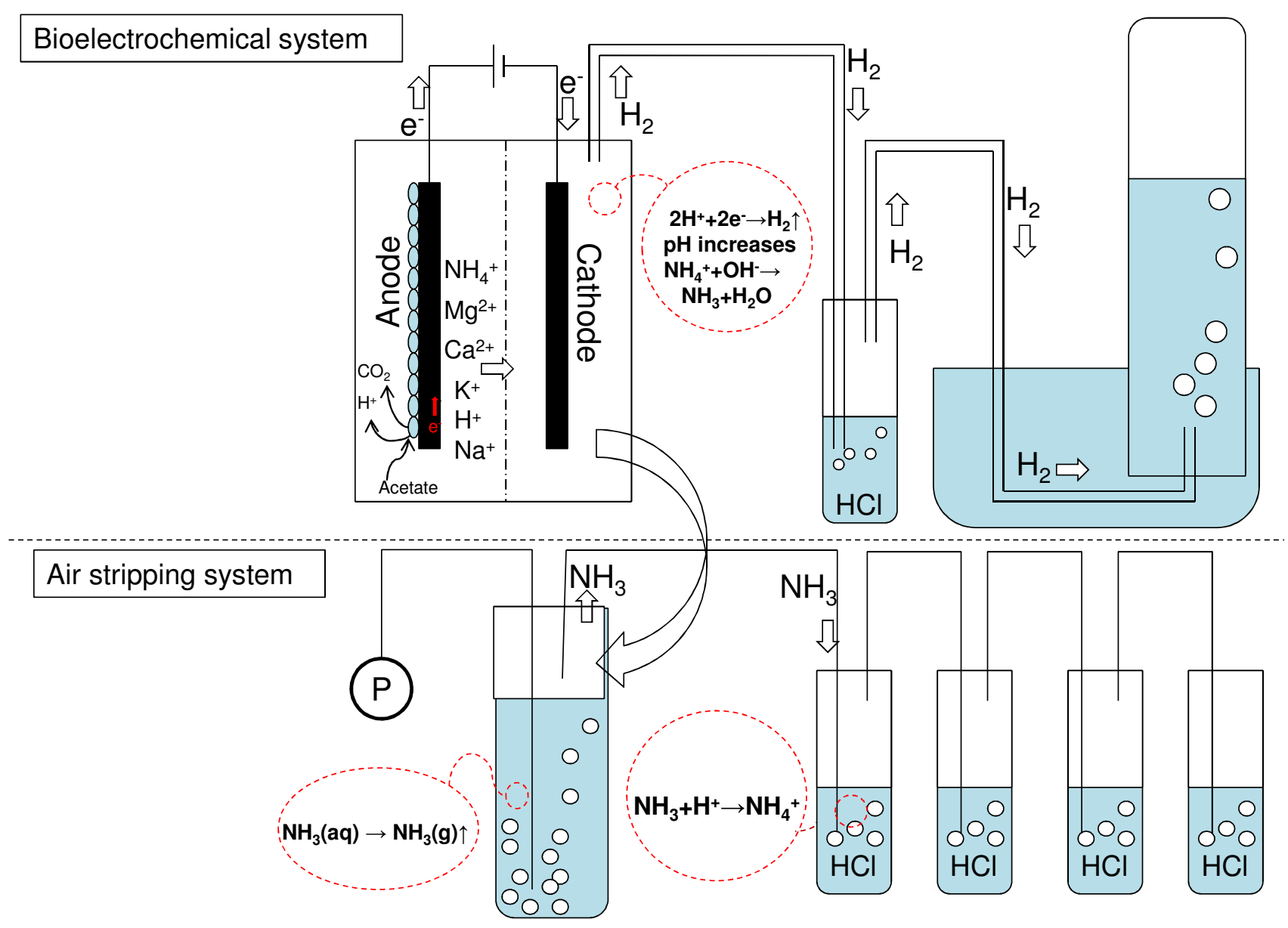

Figure 1. Schematic of the experimental setup.

\subsection{Operation}

The anode chamber was inoculated with a microbial community from a BES performing metal recovery (Modin et al., 2012). During the start-up, the anode potential was controlled at $0 \mathrm{~V}$ vs a $\mathrm{Ag} / \mathrm{AgCl}$ reference electrode (BAS Inc.) for 15 days until a biological current-generating anode had established. Then, ammonium recovery was investigated in 11 runs. Each run lasted $20 \mathrm{~h}$ and the current was controlled at 5, 10, 15, or $20 \mathrm{~mA}$ using a potentiostat (Series G750, Gamry Instruments) operating in galvanostatic mode. To volatilize the highly water soluble $\mathrm{NH}_{3}$ after each run, $40 \mathrm{~mL}$ of the catholyte was transferred to the air stripping system and stripped with an aquarium pump for approximately 20 hours at an air flow rate of $0.12 \mathrm{~L} / \mathrm{min}$.

\subsection{Analytical methods}

Total organic carbon (TOC) and total nitrogen (TN) concentrations were measured with a total organic carbon analyzer (TOC-V, Shimadzu). Alkalinity was measured by titration with $0.02 \mathrm{M} \mathrm{HCl}$ to a $\mathrm{pH}$ of 4.5. Concentrations of anion and cations were measured by ion chromatography (ICS-900, Dionex). Potentials and currents were recorded using a USB-2011 data logger (National Instruments). All electrode potentials were measured against a $\mathrm{Ag} / \mathrm{AgCl}$ reference electrode (BAS Inc.) but are reported against the standard hydrogen electrode (SHE). The reference electrode had an offset of $0.20 \mathrm{~V}$ vs SHE. The reactor was controlled using potentiostats (KP07, Bank IC or Series G750, 
Gamry). Polarization curves were obtained by controlling the current and measuring the resulting anode-, cathode-, and cell potentials. The current was varied from 0 to $51 \mathrm{~mA}$ in $3 \mathrm{~mA}$ step at a scan rate of $0.01 \mathrm{~mA} / \mathrm{s}$. The volume of $\mathrm{H}_{2}$ gas produced was measured by water displacement in a $26 \mathrm{~mm}$ diameter cylinder.

\subsection{Calculations}

The coulombic efficiencies in the reactor were calculated both for the anode $\left(\mathrm{CE}_{\mathrm{an}}\right)$ and cathode reactions $\left(\mathrm{CE}_{\mathrm{cat}}\right)$. The $\mathrm{CE}_{\mathrm{an}}$ refers to the efficiency with which organic compounds in the synthetic wastewater is converted into current and is calculated using Equation 1.

$$
\mathrm{CE}_{\mathrm{an}}=\frac{\int_{0}^{\mathrm{t}} \mathrm{Idt}}{\mathrm{F} \times \mathrm{b}_{\mathrm{e}} \times \mathrm{V} \times \Delta \mathrm{C}}
$$

with I being the current (A); $\mathrm{t}$ being the time of the bioelectrochemical reaction ( $\mathrm{s}$ ); $\mathrm{F}$ being Faraday's constant ( $96485.3 \mathrm{C} / \mathrm{mol} \mathrm{e}^{-}$); $b_{\mathrm{e}}$ being the number of electrons transferred per mol organic substrate oxidized ( $8 \mathrm{~mol} \mathrm{e} / \mathrm{mol}$ acetate); $\mathrm{V}$ being the anolyte volume (L); and $\Delta \mathrm{C}$ being the change in the concentration of the substrate $(\mathrm{mol} / \mathrm{L})$.

The $\mathrm{CE}_{\text {cat }}$ refers to the efficiency with which current is converted to hydrogen gas that is captured from the cathode chamber (Equation 2).

$$
\mathrm{CE}_{\text {cat }}=\frac{\mathrm{n}\left(\mathrm{H}_{2}\right) \times 2 \times \mathrm{F}}{\int_{0}^{\mathrm{t}} \mathrm{Idt}}
$$

with $\mathrm{n}\left(\mathrm{H}_{2}\right)$ being the amount of captured hydrogen gas in mol (calculated from the volume of produced gas using the ideal gas law) and 2 being the mol $\mathrm{e}^{-}$required per $\mathrm{mol}_{2}$.

\section{Results and discussion}

\subsection{Results overview}

During the initial enrichment period at a controlled anode potential of $0.20 \mathrm{~V}$ vs SHE, the current generated by the biological anode reached approximately $30 \mathrm{~mA}$. After the enrichment, eleven $20-\mathrm{h}$ ammonium recovery runs with controlled current conditions were carried out. A summary of the results from these runs is shown in Table 1. 
Table 1. Experimental conditions, input potential, coulombic efficiencies (CE), and ammonium recovery efficiencies in the ammonium recovery tests.

\begin{tabular}{ccccccc}
\hline Run & Catholyte & $\begin{array}{c}\text { Current } \\
(\mathbf{m A})\end{array}$ & $\begin{array}{c}\text { Input } \\
\text { potential }(\mathbf{V})\end{array}$ & $\begin{array}{c}\mathbf{C E}_{\mathbf{a n}} \\
(\boldsymbol{\%})\end{array}$ & $\begin{array}{c}\mathbf{C E}_{\text {cat }} \\
(\boldsymbol{\%})\end{array}$ & $\begin{array}{c}\mathbf{N H}_{\mathbf{4}} \text { rec. }^{\mathbf{a}} \\
(\boldsymbol{\%})\end{array}$ \\
\hline A & Synthetic & 5 & $0.94 \pm 0.04$ & 11 & 87 & 52 \\
B & Synthetic & 5 & $0.86 \pm 0.04$ & 12 & 83 & 50 \\
C & Synthetic & 10 & $1.21 \pm 0.07$ & ND & 92 & 74 \\
D & Synthetic & 10 & $1.22 \pm 0.09$ & 17 & 95 & 86 \\
E & Synthetic & 15 & $1.54 \pm 0.05$ & 55 & 98 & 82 \\
F & Synthetic & 15 & $1.48 \pm 0.08$ & 30 & 96 & 94 \\
\hline G & Real & 5 & $0.89 \pm 0.02$ & 8 & 82 & 57 \\
H & Real & 10 & $1.26 \pm 0.03$ & 18 & 93 & 65 \\
J & Real & 15 & $1.87 \pm 0.27$ & 27 & 98 & 74 \\
K & Real & 15 & $1.58 \pm 0.01$ & 30 & 94 & 73 \\
L & Real & 20 & $1.92 \pm 0.04$ & 38 & 99 & 79 \\
\hline
\end{tabular}

ND: Not determined.

${ }^{\mathrm{a}}$ Fraction of ammonium in the reject water that was recovered in acid after air stripping.

\subsection{Anodic oxidation of organics}

The synthetic wastewater fed to the anode chamber was exchanged every three runs to ensure that lack of organic substrate did not limit the performance of the reactor. The concentration of dissolved organic carbon typically ranged from as high as $460 \mathrm{mg} / \mathrm{L}$ just after supplying fresh feed to the anode chamber, to as low as $50 \mathrm{mg} / \mathrm{L}$ after three 20 -h runs. Theoretically, the consumption of organic carbon in each run should have corresponded to current charge transfer in the system. However, there was no clear correlation between organic carbon consumption and charge transfer $\left(\mathrm{R}^{2}\right.$ value for the linear regression was 0.025 ; Figure $\mathrm{S} 1$ in the supplementary material). The reason for this could have been that other reactions contributed to organic carbon removal in the system; for example, methanogenesis, sulfate reduction, or aerobic oxidation caused by air leaking into the reactor. However, the contributions of these reactions were not quantified. The anodic $\mathrm{CE}$ was quite low and ranged from $8 \%$ to $55 \%$. The $\mathrm{CE}_{\mathrm{an}}$ was generally higher when the current was higher (see Table 1). The $\mathrm{CE}_{\mathrm{an}}$ is a variable whose value depends on many parameters such as the incubated microorganisms, the properties of the wastewater, the duration of the reaction, as well as the system design (Sleutels et al., 2011).

\subsection{Cathodic production of $\mathbf{H}_{2}$}

As shown in Figure 2, the volume of produced hydrogen gas increased significantly as the current increased from 5 to $20 \mathrm{~mA}$, and there was no observable difference between synthetic and real reject water as catholyte. The $\mathrm{CE}_{\text {cat }}$ ranged from $82 \%$ (run $\mathrm{G}$ ) to $99 \%$ (run $\mathrm{L}$ ). The $\mathrm{CE}_{\text {cat }}$ generally increased with increasing current (Table 1), possibly because the impact of small gas leakages in tubing connections was smaller at higher gas production rate. Based on all the 11 runs, the overall $\mathrm{CE}_{\text {cat }}$ was $96 \pm 6 \%$ at a $95 \%$ confidence level (see Section S2 in the supplementary material) 
Assuming that hydrogen has an energy value $285.83 \mathrm{~kJ} / \mathrm{mol}$ (Call \& Logan, 2008), the energy efficiency in terms of hydrogen production can be calculated by dividing the energy value of the produced hydrogen with the electrical energy input to the bioelectrochemical reactor. It ranged from $76 \%$ in the run with the highest input potential (run L) to $142 \%$ in the run with the lowest input potential (run B).

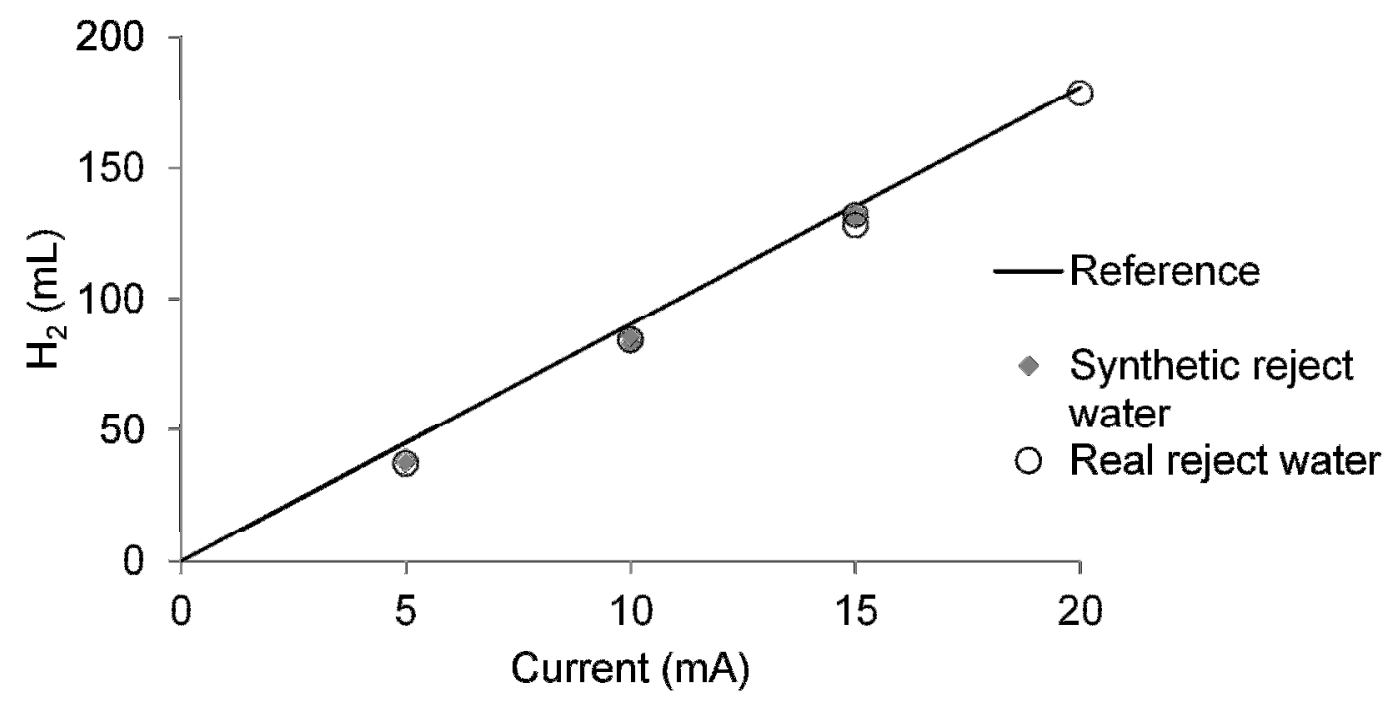

Figure 2. Produced hydrogen gas as a function of current. The solid reference indicates $100 \%$ efficiency in converting current into hydrogen gas.

\subsection{Increase of catholyte $\mathrm{pH}$}

As hydrogen gas was produced in the cathode chamber, the $\mathrm{pH}$ of the catholyte also increased (Figure 3A-B). The $\mathrm{pH}$ increased more in the synthetic reject water compared to the real reject water at the same current. This occurred because the real reject water had a higher buffer capacity. Comparing the change in alkalinity concentration (Figure 3C), it can be seen that there was no clear difference in the alkalinity change between the real and synthetic reject water. Ideally each current charge transfer would correspond to an equivalent increase in alkalinity concentration. The efficiency with which current charge transfer resulted in alkalinity increase in the cathode compartment was $84 \pm 16 \%$ at a $95 \%$ confidence level (see Section S3 in the supplementary material). Issues that could potentially lower the efficiency in the system include migration of $\mathrm{H}^{+}$ions from the anode chamber to the cathode chamber or precipitation of e.g. $\mathrm{CaCO}_{3}$ in the cathode chamber.

The increase of catholyte $\mathrm{pH}$ and alkalinity can be explained by consumption of hydrogen ions at the cathode and migration of cations from the anode chamber to the cathode chamber. In the reactor, as electrons are transferred from the anode to the cathode, there should be an inverse equimolar positive charge transfer from the anode to the cathode to maintain electroneutrality of the system. Since there was a cation exchange membrane in the reactor, cations such as $\mathrm{Na}^{+}, \mathrm{K}^{+}, \mathrm{Ca}^{2+}, \mathrm{Mg}^{2+}, \mathrm{NH}_{4}^{+}$, and $\mathrm{H}^{+}$ in the anolyte could have been responsible for the positive charge transfer. In Figure 3D, it can be seen that most of the charge migration in the system was accomplished by $\mathrm{Na}^{+}$and $\mathrm{K}^{+}$ions. 

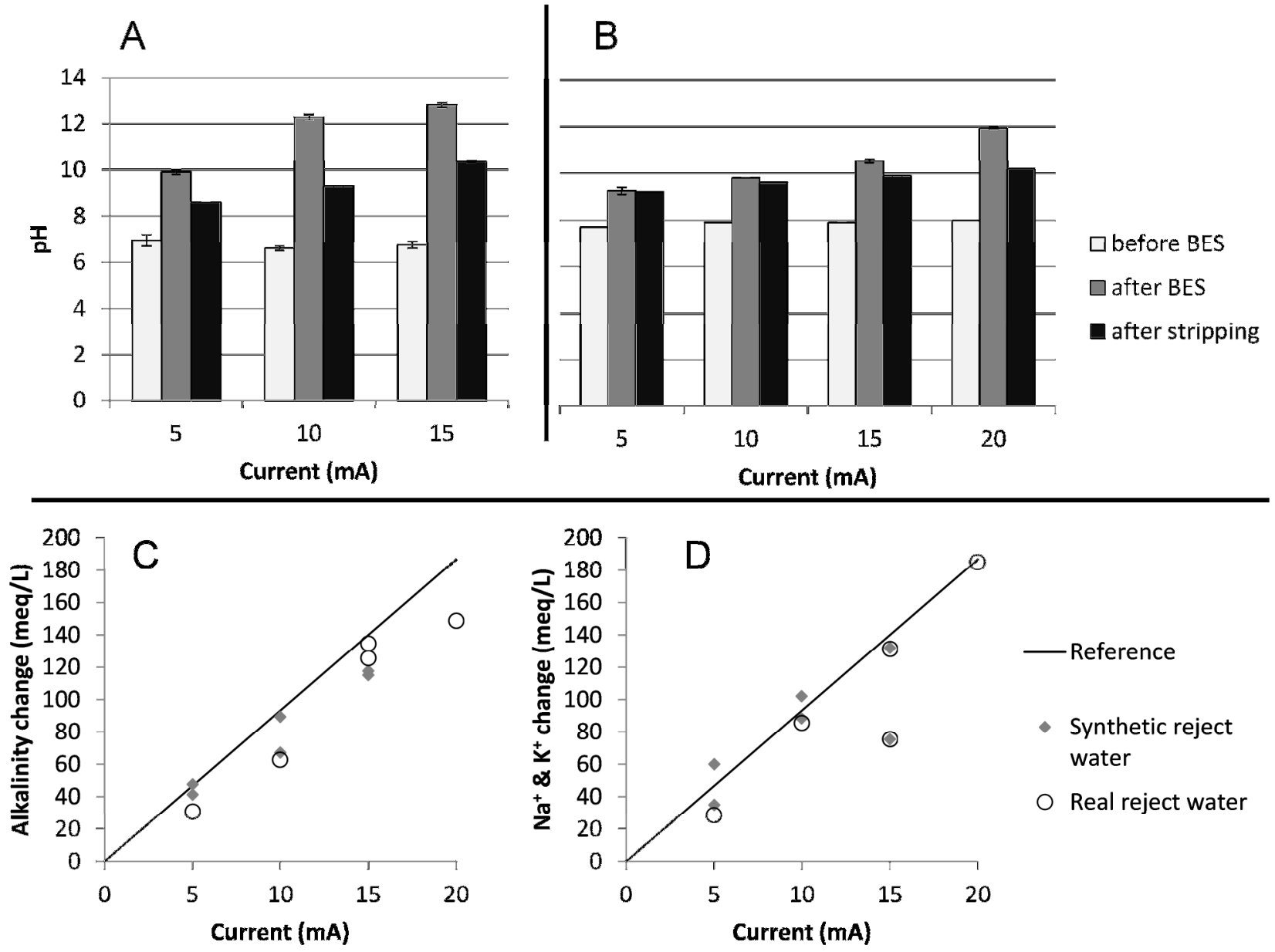

Figure 3. Changes in catholyte $\mathrm{pH}$ in the synthetic (A) and real reject water (B), and changes in alkalinity concentration (C), and $\mathrm{Na}^{+}$and $\mathrm{K}^{+}$concentrations (D) as functions of current. The solid reference line shows when the current results in alkalinity increase with $100 \%$ efficiency.

\subsection{Recovery of ammonium}

The TN concentration was measured in the catholyte before and after the bioelectrochemical reaction, and before and after air stripping. The results are shown in Figure 4. During the 20-h bioelectrochemical reaction, the change in TN concentration in the catholyte was very small. The hydrogen gas bubbles produced were not sufficient to volatilize the ammonia. Only low concentrations of TN $(0-60 \mathrm{mg} / \mathrm{L})$ could be measured in the acid adsorbent used to capture ammonia from the hydrogen gas during the bioelectrochemical reaction. Thus, a stripping method was necessary to recover ammonia from the alkalized reject water. After 20 hours of air stripping, the concentration of $\mathrm{TN}$ in the catholyte decreased significantly. The efficiency with which the stripped ammonia was recovered in acid was high, ranging from $87 \%$ to $100 \%$, (the average recovery was $95 \pm 5 \%$ for the eleven runs). Although there were four acid tubes connected in series in the air stripping system, nearly all of the nitrogen was recovered in the first tube.

For both the synthetic and real reject water, more nitrogen could generally be recovered from the runs 
with higher current. This is because the catholyte $\mathrm{pH}$ increased more when the current was higher. Ammonium has an acid dissociation constant of $10^{-9.25}$, which means that at a $\mathrm{pH}$ of 9.25 about half of the ammonia will be present as $\mathrm{NH}_{3}$ and the other half as $\mathrm{NH}_{4}{ }^{+}$. At a pH of $10.5,95 \%$ should be present as $\mathrm{NH}_{3}$. With synthetic reject water, the $\mathrm{pH}$ of the catholyte increased to over 12 when the current was 10 or $15 \mathrm{~mA}$. Consequently, most of the ammonium could be recovered in acid after these runs. In the runs at $5 \mathrm{~mA}$, the catholyte $\mathrm{pH}$ was less than 10 and only about half of the ammonium could be recovered. During air stripping of synthetic reject water, the $\mathrm{pH}$ dropped significantly (Figure 3A-B), possibly because of dissolution of carbon dioxide from air. For example, in the runs at $5 \mathrm{~mA}$, the $\mathrm{pH}$ dropped from 9.9 to 8.6. With real reject water, the increase in $\mathrm{pH}$ in the BES was lower, which meant that a lower fraction of the nitrogen could be recovered compared to the synthetic reject water. However, the drop in $\mathrm{pH}$ during air stripping was also smaller. For example, at $5 \mathrm{~mA}$ the $\mathrm{pH}$ only dropped from 9.4 to 9.2 .

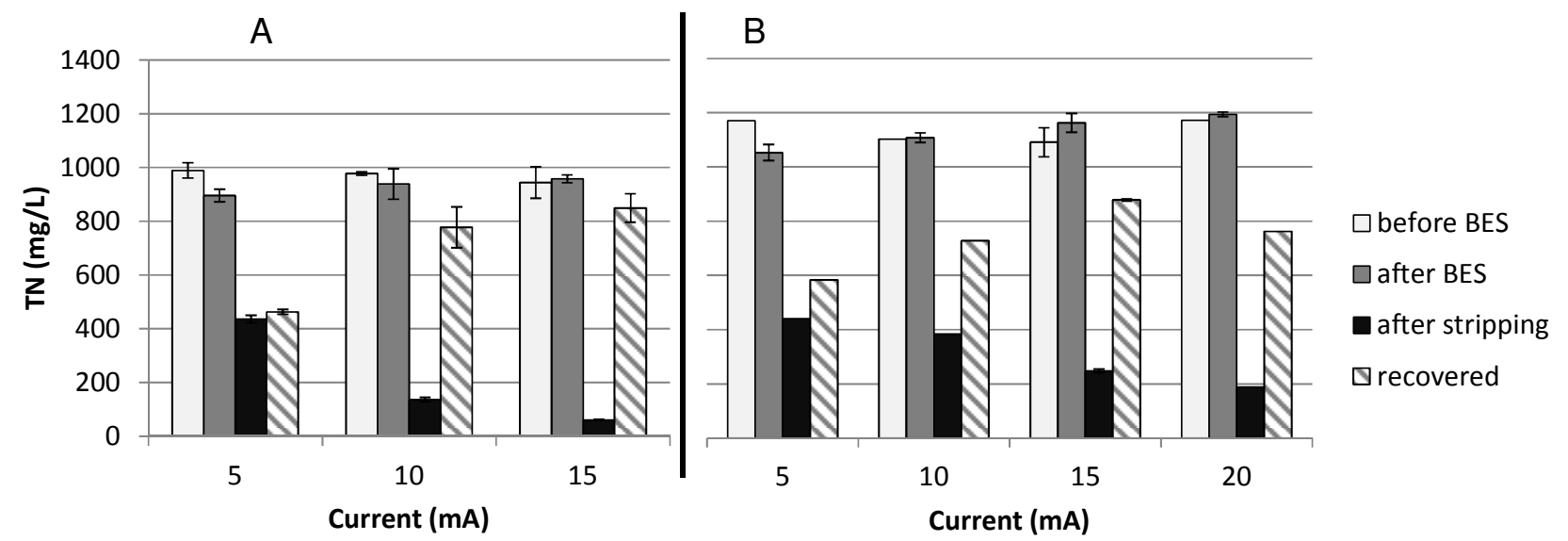

Figure 4. Nitrogen recovery from synthetic (A) and real reject water (B). "before BES" refers to total nitrogen (TN) concentration in the catholyte at the beginning of each run, "after BES" is the concentration after $20 \mathrm{~h}$ of reaction in the bioelectrochemical system, "after stripping" is the concentration after $20 \mathrm{~h}$ of air stripping, and "recovered" is the amount of nitrogen recovered in acid normalized to the volume of the catholyte.

\subsection{Electrochemical characterization of the reactor}

Polarization curves were obtained at the end of the experiment (Figure 5). The negative cell potential means that electrical energy input is needed to drive the reactions. The anode potential curves show a dramatic growth at currents over $48 \mathrm{~mA}$ indicating that this is the limit for the electrochemically active microbial community on the anode. Running the reactor at higher currents could result in e.g. water oxidation or electrochemical oxidation of biomass components, which could damage the microbial community. The cathode potential rapidly drops to about $-1.2 \mathrm{~V}$ vs SHE where hydrogen generation occurs. The cathode potential is slightly lower with synthetic reject water, possibly because of a more rapid rise in $\mathrm{pH}$ which shifts the $\mathrm{H}^{+} / \mathrm{H}_{2}$ reduction potential in a more negative direction. The internal resistance of the reactor can be calculated from the slope of the linear portion of the cell potential curves. With synthetic reject water the resistance was $72 \pm 2 \Omega$ and with real it was $54 \pm 1 \Omega$ (see Section S4 in the supplementary material). 

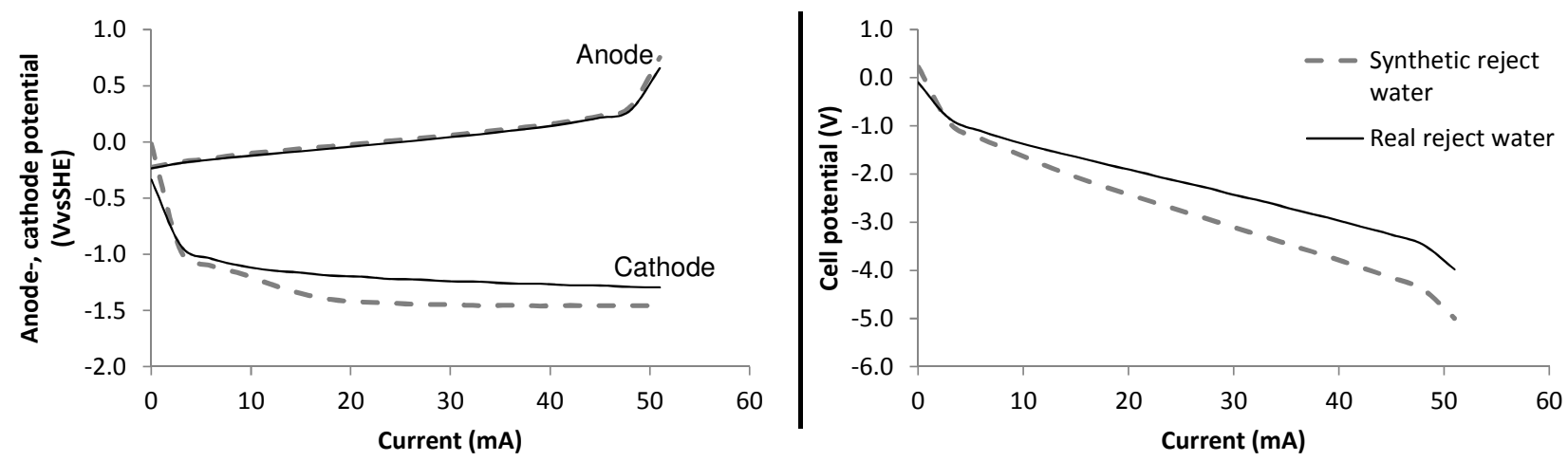

Figure 5. Polarization curves for the bioelectrochemical reactor obtained with either synthetic (grey dashed line) of real reject water (solid black line) as catholyte.

\subsection{Implications}

A simple energetic analysis of the nitrogen recovery process proposed in this paper is shown in Table 2. This shows that when considering only the electrical energy input to the bioelectrochemical reactor, the energy content of the produced $\mathrm{H}_{2}$ gas, and the energy savings involved in replacing ammonia produced using the Haber-Bosch process, the overall process is energetically favorable with a net energy balance ranging from 5.4 to $12.4 \mathrm{kWh} / \mathrm{kgN}$. These calculations do not consider energy consumption by the air stripping method used to volatilize ammonia in this study. However, it should be noted that other methods such as diffusion through a membrane could potentially be used for more energy-efficient ammonia capture. By circulating a diluted acid through a microporous hydrophobic membrane submerged in liquid manure or poultry litter, researchers have shown that ammonia can be efficiently captured from manure and concentrated in the acid (Rothrock Jr. et al., 2010; Vanotti \& Szogi, 2010).

Table 2. Energy balance for the ammonium recovery tests.

\begin{tabular}{|c|c|c|c|c|}
\hline Run & $\begin{array}{c}\text { Electric energy } \\
(\mathrm{kWh} / \mathrm{kgN})\end{array}$ & $\begin{array}{c}\mathrm{H}_{2} \text { energy } \\
(\mathrm{kWh} / \mathrm{kgN})\end{array}$ & $\begin{array}{c}\mathrm{NH}_{3} \text { energy equiv. } \\
(\mathrm{kWh} / \mathrm{kgN})\end{array}$ & $\begin{array}{c}\text { Net energy balance } \\
(\mathbf{k W h} / \mathbf{k g N})\end{array}$ \\
\hline $\mathrm{A}$ & -5.0 & 6.8 & 10.3 & 12.2 \\
\hline $\mathrm{B}$ & -4.8 & 6.8 & 10.3 & 12.4 \\
\hline $\mathrm{C}$ & -8.6 & 9.7 & 10.3 & 11.3 \\
\hline $\mathrm{D}$ & -7.2 & 8.2 & 10.3 & 11.4 \\
\hline $\mathrm{E}$ & -14.5 & 13.7 & 10.3 & 9.5 \\
\hline $\mathrm{F}$ & -12.3 & 11.9 & 10.3 & 9.9 \\
\hline $\mathrm{G}$ & -3.8 & 5.2 & 10.3 & 11.7 \\
\hline $\mathrm{H}$ & -8.6 & 9.5 & 10.3 & 11.2 \\
\hline $\mathbf{J}$ & -15.9 & 12.3 & 10.3 & 6.7 \\
\hline $\mathrm{K}$ & -13.6 & 12.0 & 10.3 & 8.7 \\
\hline $\mathrm{L}$ & -20.5 & 15.7 & 10.3 & 5.4 \\
\hline
\end{tabular}

${ }^{a}$ Assumed energy consumption of the Haber-Bosch process (Maurer et al., 2003) 
The process could fit into an existing municipal wastewater treatment plant according to the process schematic shown in Figure 6. A portion of the wastewater exiting the primary settlers would be passed through the anode chamber to provide dissolved organics as substrate for the biological anode. The reject water from the sludge treatment processes would be passed through the cathode chamber where hydrogen is generated and ammonia is volatilized and captured in acid. Assuming the influent wastewater flow is 100 times larger than the reject water flow, and a catholyte alkalinity change of 130 $\mathrm{meq} / \mathrm{L}$ is necessary to recover most of the ammonia (this is equivalent to the $15 \mathrm{~mA}$ runs $(\mathrm{J} \& \mathrm{~K}$ ) recovering $73-74 \%$ of the ammonia in this study), the consumption of organics needed to generate the required current at the anode would equal $10.4 \mathrm{mgBOD} / \mathrm{L}$. Thus, availability of organic substrate will not limit the process, as this is only a fraction of the dissolved organics usually present in municipal wastewater.

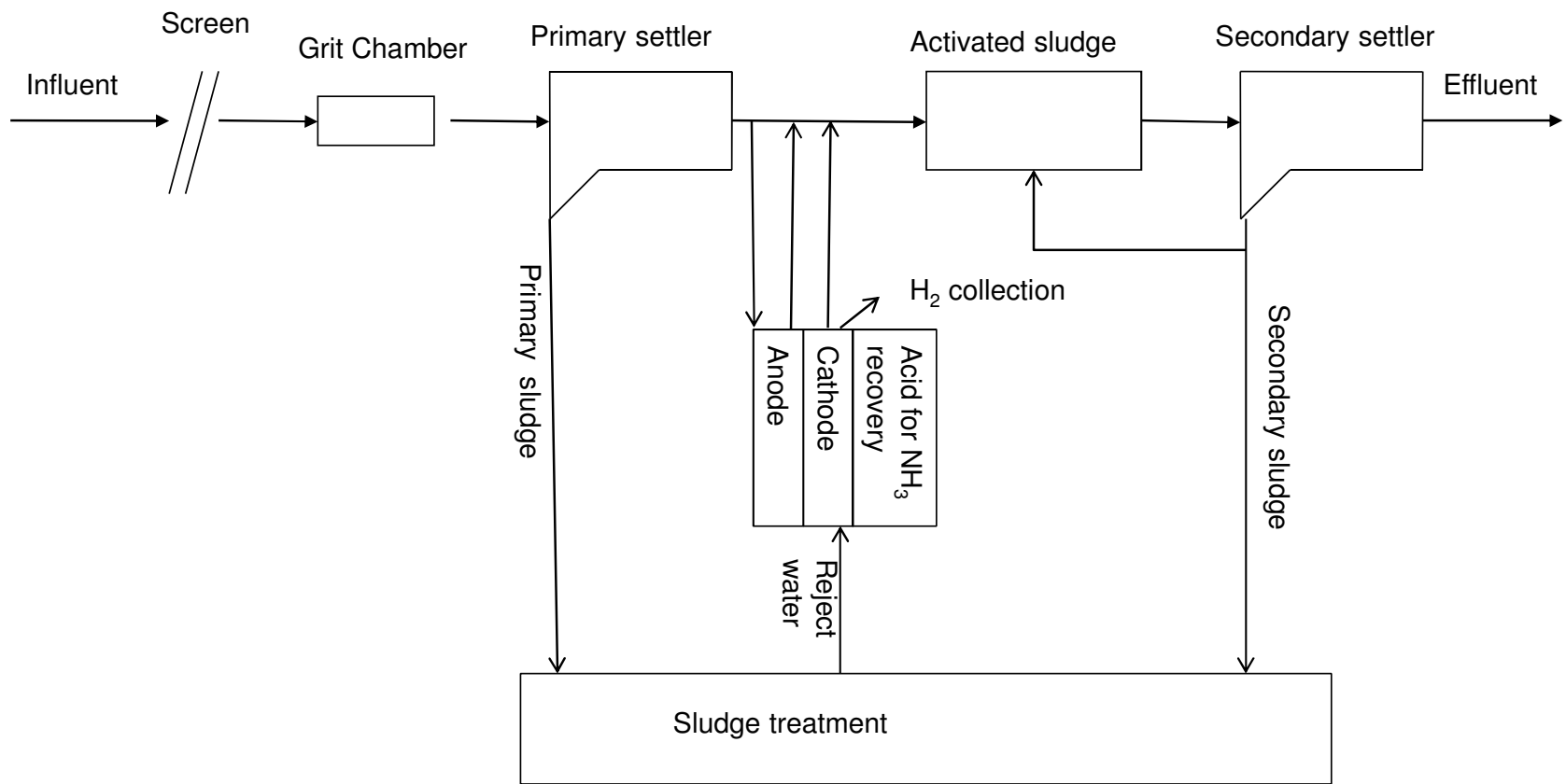

Figure 6. Schematic of a wastewater treatment plant with integrated microbial electrolysis cell for ammonia recovery.

\section{Conclusions}

A new bioelectrochemical method for hydrogen production and nitrogen recovery from reject water at wastewater treatment plants was demonstrated. The reactor produced hydrogen gas with a cathodic $\mathrm{CE}$ of $96 \pm 6 \%$ and the flow of current generated a $\mathrm{pH}$ increase at the cathode which led to ammonium being transformed into volatile ammonia. Very little ammonia gas was stripped from the reject water with the generated hydrogen gas. However, with subsequent air stripping, up to $79 \%$ of the ammonia could be recovered in acid from real reject water. The process could potentially contribute to transforming wastewater treatment plants into resource recovery plants. 


\section{Acknowledgements}

O.M. was supported by a Marie Curie career integration grant (bioanode) from the European Commission and a grant from the Swedish Research Council (VR, project 2010-612).

\section{References}

1 Arnold, E., Böhm, B., Wilderer, P.A. 2000. Application of activated sludge and biofilm sequencing batch reactor technology to treat reject water from sludge dewatering systems: a comparison. Water Science \& Technology, 41, 115-122.

2 Call, D., Logan, B.E. 2008. Hydrogen production in a single chamber microbial electrolysis cell lacking a membrane. Environmental Science \& Technology, 42, 3401-3406.

3 Desloover, J., Woldeyohannis, A.A., Verstraete, W., Boon, N., Rabaey, K. 2012. Electrochemical resource recovery from digestate to prevent ammonia toxicity during anaerobic digestion. Environmental Science \& Technology, 46, 12209-12216.

4 Fux, C., Boehler, M., Huber, P., Brunner, I., Siegrist, H. 2002. Biological treatment of ammonium-rich wastewater by partial nitritation and subsequent anaerobic ammonia oxidation (anammox) in a pilot plant. Journal of Biotechnology, 99, 295-306.

5 Jetten, M.S.M., Strous, M., van de Pas-Schoonen, K.T., Schalk, J., van Dongen, U.G.J.M., van de Graaf, A.A., Logemann, S., Muyzer, G., van Loosdrecht, M.C.M., Kuenen, J.G. 1999. The anaerobic oxidation of ammonium. FEMS Microbiology Reviews, 22, 421-437.

6 Kuntke, P., Geleji, M., Bruning, H., Zeeman, G., Hamelers, H.V., Buisman, C.J. 2011. Effects of ammonium concentration and charge exchange on ammonium recovery from high strength wastewater using a microbial fuel cell. Bioresource Technology, 102, 4376-4382.

7 Kuntke, P., Smiech, K.M., Bruning, H., Zeeman, G., Saakes, M., Sleutels, T.H., Hamelers, H.V., Buisman, C.J. 2012. Ammonium recovery and energy production from urine by a microbial fuel cell. Water Research, 46, 2627-2636.

8 Logan, B.E., Call, D., Cheng, S., Hamelers, H.V.M., Sleutels, T.H.J.A., Jeremiasse, A.W., Rozendal, R.A. 2008. Microbial electrolysis cells for high yield hydrogen gas production from organic matter. Environmental Science \& Technology, 42, 8630-8640.

9 Logan, B.E., Hamelers, H., Rozendal, R., Schröder, U., Keller, J., Freguia, S., Aelterman, P., Verstraete, W., Rabaey, K. 2006. Microbial fuel cells: Methodology and technology. Environmental Science \& Technology, 40, 5181-5192.

10 Maurer, M., Schwegler, P., Larsen, T.A. 2003. Nutrients in urine: energetic aspects of removal and recovery. Water Science \& Technology, 48, 37-46.

11 Modin, O., Fukushi, K., Rabaey, K., Rozendal, R.A., Yamamoto, K. 2011. Redistribution of wastewater alkalinity with a microbial fuel cell to support nitrification of reject water. Water Research, 45, 2691-2699.

12 Modin, O., Wang, X., Wu, X., Rauch, S., Fedje, K.K. 2012. Bioelectrochemical recovery of Cu, Pb, Cd, and Zn from dilute solutions. Journal of Hazardous Materials, 235-236, 291-297.

13 Rothrock Jr., M.J., Szögi, A.A., Vanotti, M.B. 2010. Recovery of ammonia from poultry litter using gas-permeable membranes. Transactions of the ASABE, 53, 1267-1275.

14 Rozendal, R.A., Hamelers, H.V., Rabaey, K., Keller, J., Buisman, C.J. 2008. Towards practical implementation of bioelectrochemical wastewater treatment. Trends in Biotechnology, 26, 
450-459.

15 Rozendal, R.A., Hamelers, H.V.M., Buisman, C.J.N. 2006. Effects of membrane cation transport on $\mathrm{pH}$ and microbial fuel cell performance. Environmental Science \& Technology, 40, 5206-5211.

16 Sleutels, T.H., Darus, L., Hamelers, H.V., Buisman, C.J. 2011. Effect of operational parameters on coulombic efficiency in bioelectrochemical systems. Bioresource Technology, 102, 11172-11176.

17 Smith, B.E. 2002. Nitrogenase reveals its inner secrets. Science, 297, 1654-1655.

18 Vanotti, M.B., Szogi, A.A. 2010. Removal and recovery of ammonia from liquid manure using gas-permeable membranes. ASABE Annual International Meeting, Pittsburgh, Pennsylvania, USA. 


\title{
SUPPLEMENTARY MATERIAL
}

\section{Ammonium recovery from reject water combined with hydrogen production in a bioelectrochemical reactor}

\author{
Xue Wu, Oskar Modin
}

\section{Section S1}

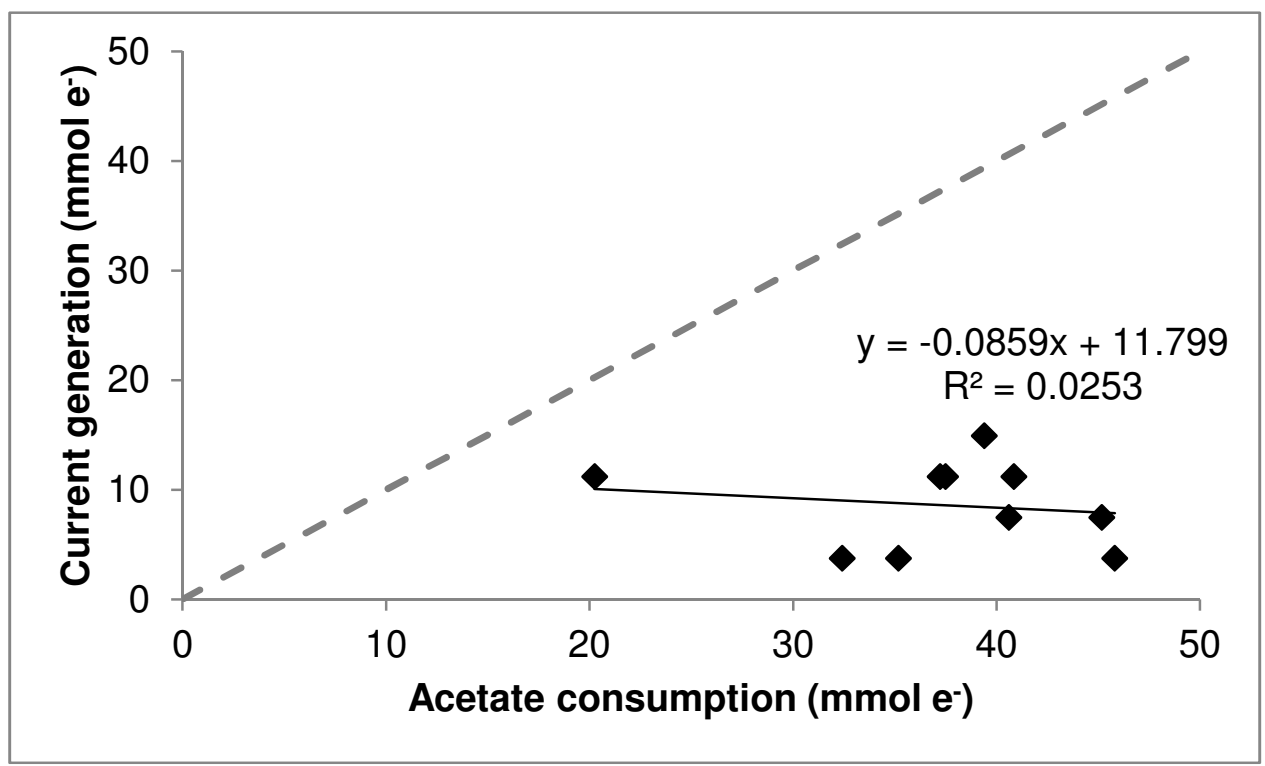

Figure S1. Correlation between acetate consumption and current generation in the bioelectrochemical reactor. At $100 \%$ anodic coulombic efficiency, there would be a 1:1 correlation between acetate consumption and current generation as illustrated by the grey dashed line. 


\section{Section S2}

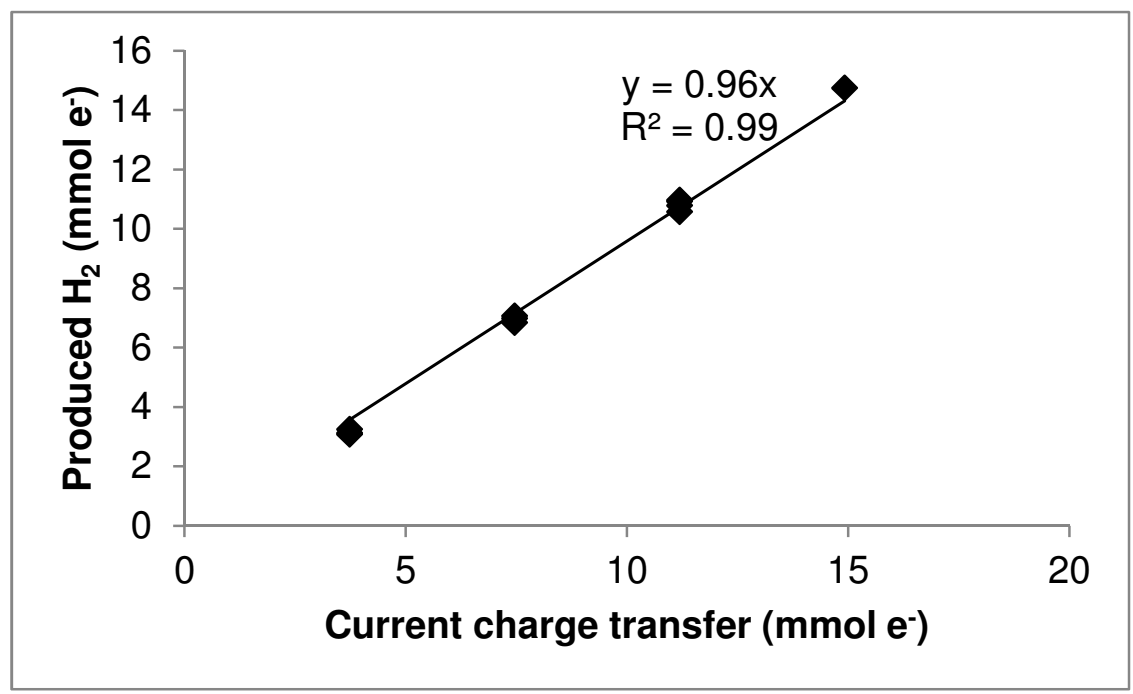

Figure S2. Correlation between current charge transfer and hydrogen production in the bioelectrochemical reactor.

\section{Calculation of confidence interval for the efficiency with which current charge transfer results in hydrogen production:}

The slope of the linear regression of the data in Figure S2 shows the efficiency with which current charge transfer results in hydrogen production.

The standard error (SE) of the data is calculated using Equation S1.

$S E=\frac{\sqrt{\left(y_{i}-\widehat{\left.y_{l}\right)^{2} /(n-2)}\right.}}{\sqrt{\left(x_{i}-\bar{x}\right)^{2}}}$

where $y_{i}$ is the measured value of the dependent variable for the $i^{\text {th }}$ observation (hydrogen production), $\widehat{y}_{l}$ is the estimated value of the dependent variable, $\mathrm{n}$ is the number of observations, $x_{i}$ is the value of the independent variable (current charge transfer), and $\bar{x}$ is the mean of the independent variable.

For the data in Figure S2, SE was calculated to 0.03.

The errors in the linear regression are assumed to be normally distributed and a $t$-value is found from the Student's t-distribution for a confidence level of $95 \%$. The degrees of freedom (df) is 9 (i.e. $n-2)$, and the $t$-value is 2.262 .

The margin of error for the slope is calculated by multiplying the t-value and the SE.

Margin of error $=0.03 \times 2.262=0.06$

The means that at a 95\% confidence level, the efficiency with which current charge transfer resulted in alkalinity change in the bioelectrochemical reactor was $96 \pm 6 \%$. 


\section{Section S3}

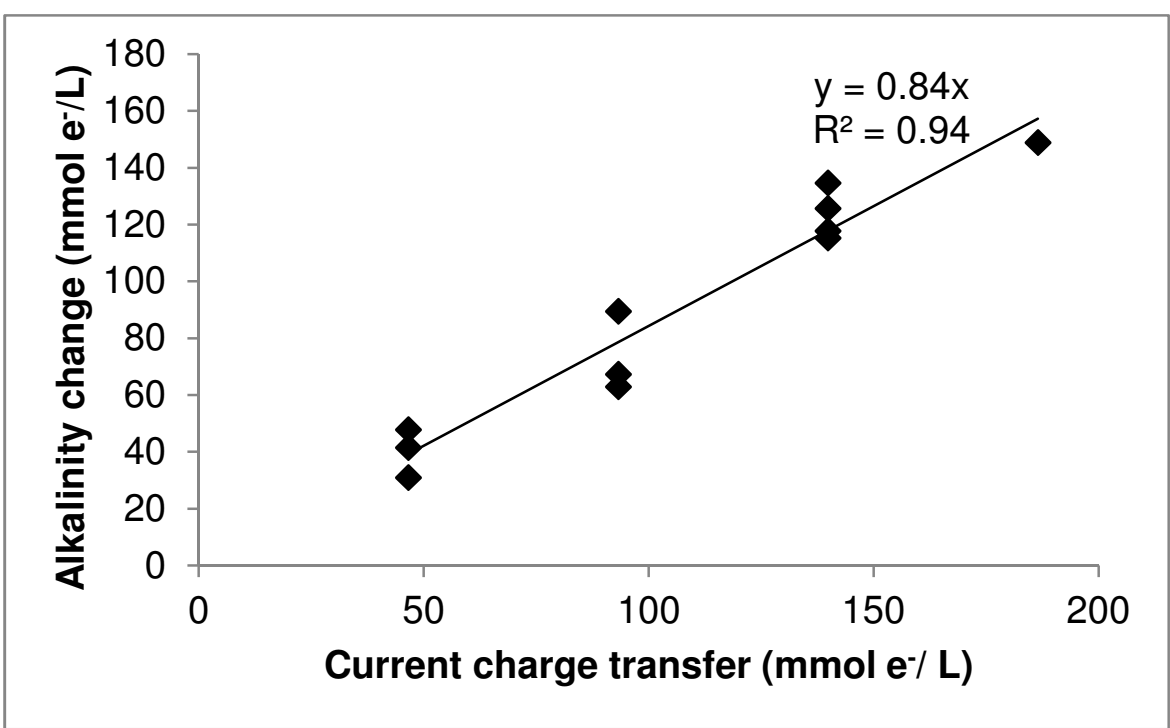

Figure S3. Correlation between current charge transfer and alkalinity change in the bioelectrochemical reactor.

The confidence interval for the efficiency with which current was converted into alkalinity change at the cathode was calculated using the same methodology as in Section S2 above.

At a $95 \%$ confidence level, the efficiency was $84 \pm 16 \%$. 
Section S4

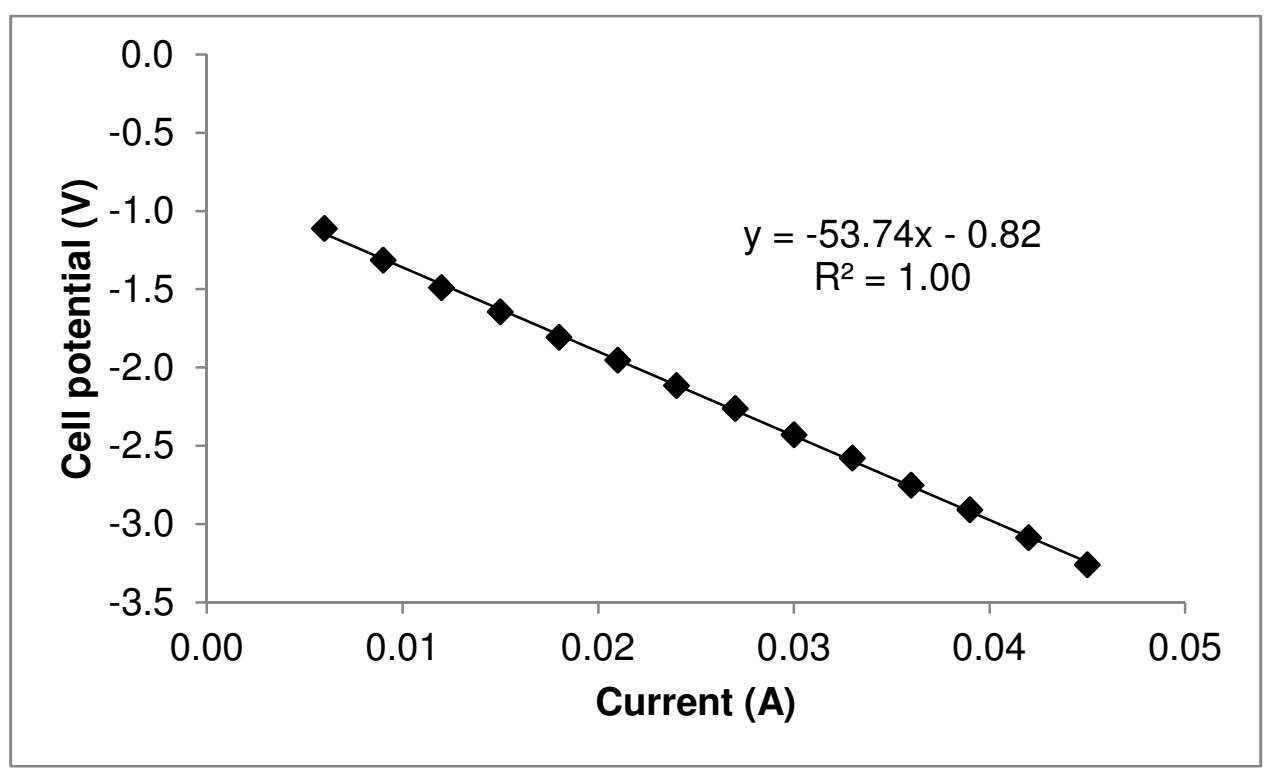

Figure S4. Correlation between current and cell potential with real reject water as catholyte. At a 95\% confidence level, the internal resistance was $54 \pm 1 \Omega$.

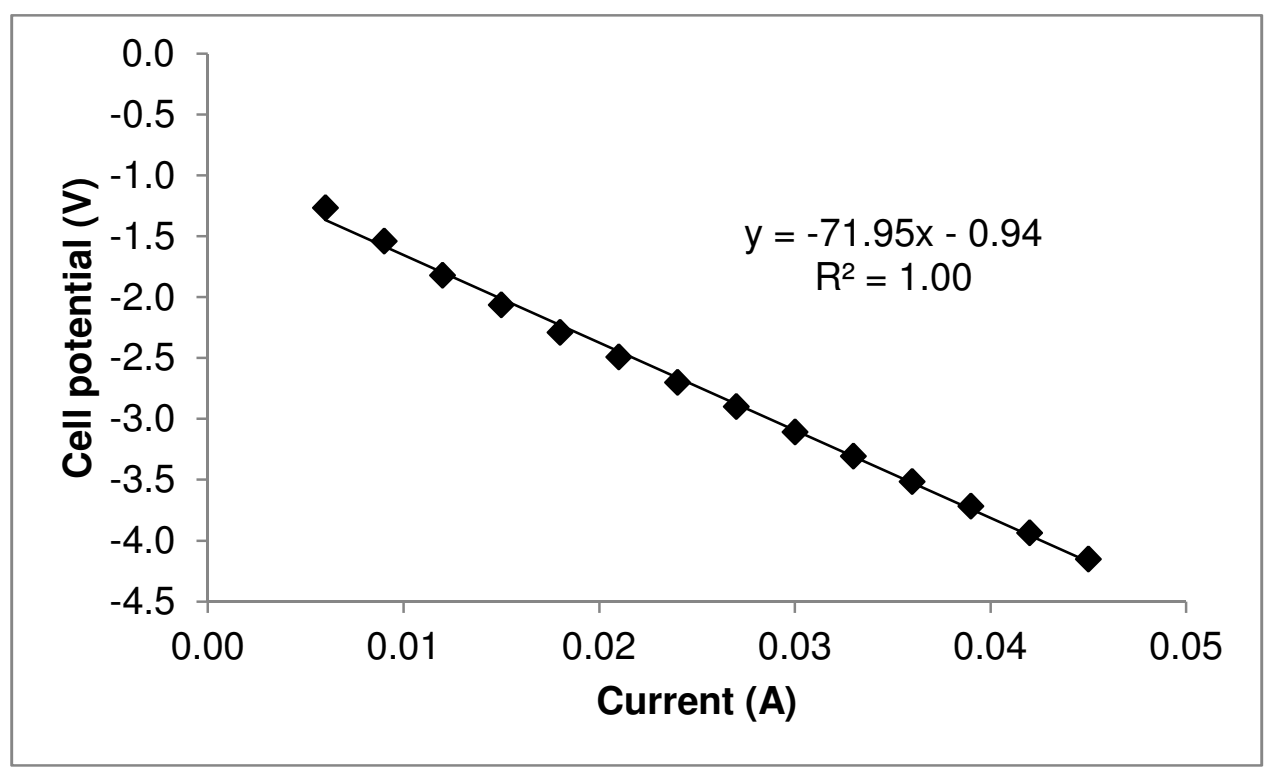

Figure S5. Correlation between current and cell potential with synthetic reject water as catholyte. At a $95 \%$ confidence level, the internal resistance was $72 \pm 2 \Omega$. 